\title{
Comparison of different treatment approaches in chronic non-bacterial osteomyelitis.
}

\author{
M Kostik ${ }^{1 *}$, I Chikova', V Masalova', M Dubko' ${ }^{1}$ L Snegireva', E Isupova', O Kalashnikova', V Avramenko², \\ A Denisov², D Vorypin², D Philippov², S Peredereev², D Malamashin ${ }^{3}$, A Pershin ${ }^{3}$, E Malyarova $^{3}$, M Bakin ${ }^{3}$, \\ $\checkmark$ Evseev $^{3}$, A Mushkin $^{3}$, V Chasnyk ${ }^{1}$
}

From 8th International Congress of Familial Mediterranean Fever and Systemic Autoinflammatory Diseases Dresden, Germany. 30 September - 3 October 2015

Chronic non-bacterial osteomyelitis (CNO) is a heterogenous group of immune-mediated inflammatory bone diseases, which often co-exist with other rheumatic diseases. There are no approved treatments for $\mathrm{CNO}$, except nonsteroid anti-inflammatory drugs (NSAID). The efficacy of methotrexate (MTX), sulfasalazine, pamidronate (PAM), anti-IL1 and TNF $\alpha$-inhibitors was shown in different reports, but there are some concerns about safety of pamidronate due to long-term accumulation and persistation in bone.

The aim of our study was to compare the efficacy of non-randomized different treatment approaches in pediatric patient cohort with $\mathrm{CNO}$.

\section{Materials}

37 children (16 M and $21 \mathrm{~F}$ ) with $\mathrm{CNO}$ from medical centers in Saint Petersburg. The average age at the onset of disease was 8.5 years $(5.9 \div 10.5)$, the number of foci $3.0(2.0 \div 6.5$, incl. multifocal cases in $78.4 \%)$, fever at the onset $-37.8 \%$, spine involvement $-32.4 \%$, positive family autoimmune diseases (AID) history - $8.1 \%$, concomitant AID - 64.9\%. NSAID was the first-line treatment for nonvertebral cases, as well as PAM for vertebral involvement. Second-line treatment includes MTX, PAM and TNF $\alpha$ inh. Dynamics of pain, patient's (PVAS) and physician's (MDVAS) assessment of $\mathrm{CNO}$ activity we evaluated.

\section{Results}

According to the NSAID, MTX, PAM and TNF $\alpha$-inh groups next data were registered:

PVAS: $-26.2 \%(\mathrm{p}=0.05),-14.6 \% \quad(\mathrm{p}=0.06),-84.7 \%$ $(\mathrm{p}=0.0002),-75.6 \%(\mathrm{p}=0.012)$; pain: $-36.4 \%(\mathrm{p}=0.028),-15.6 \% \quad(\mathrm{p}=0.31),-84.8 \%$ $(\mathrm{p}=0.0002),-82.6 \%, \mathrm{p}=0.012)$;

MDVAS: $-33.8 \%(\mathrm{p}=0.08) ;+2.4 \%(\mathrm{p}=0.24),-81.4 \%$ $(\mathrm{p}=0.0002),-75.8 \%,(\mathrm{p}=0.012)$, respectively.

The therapy was effective in $38.9 \%, 57.1 \%, 83.3 \%$ and $88.8 \%$ respectively (log-rank test, $\mathrm{p}=0.012$ ). TNF $\alpha$-inh usually used as second-third line treatment in cases where other options, especially PAM were fall.

\section{Conclusions}

The most effective treatment approaches for $\mathrm{CNO}$ were PAM and TNF $\alpha$-inh. The randomized controlled trials for assessment efficacy and safety of these medications is mandatory to confirm these results.

\section{Authors' details}

'Saint-Petersburg State Pediatric Medical University, Hospital Pediatry, Saint Petersburg, Russian Federation. ${ }^{2}$ Saint-Petersburg State Pediatric Medical University, Pediatric Surgery, Saint Petersburg, Russian Federation. ${ }^{3}$ Federal State Budget Institue "Science research Institute of Phthisiopulmonology Ministry of Health RF", Pediatric Surgery, Saint Petersburg, Russian Federation.

Published: 28 September 2015

doi:10.1186/1546-0096-13-S1-P203

Cite this article as: Kostik et al:: Comparison of different treatment approaches in chronic non-bacterial osteomyelitis.. Pediatric Rheumatology 2015 13(Suppl 1):P203.

'Saint-Petersburg State Pediatric Medical University, Hospital Pediatry, Saint

Petersburg, Russian Federation

Full list of author information is available at the end of the article

(c) 2015 Kostik et al. This is an Open Access article distributed under the terms of the Creative Commons Attribution License (http:// creativecommons.org/licenses/by/4.0), which permits unrestricted use, distribution, and reproduction in any medium, provided the original work is properly cited. The Creative Commons Public Domain Dedication waiver (http://creativecommons.org/publicdomain/ zero/1.0/) applies to the data made available in this article, unless otherwise stated. 